1 Accepted to Environmental Reviews

2

\title{
3 Geography of global change and species richness in the North
}

4

$5 \quad$ Annika Vilmia ${ }^{\mathrm{a}, \mathrm{b}}$, Janne Alahuhta ${ }^{\mathrm{c}}$, Jan Hjort ${ }^{\mathrm{c}}$, Olli-Matti Kärnäc ${ }^{\mathrm{c}}$, Kirsti Leinonen ${ }^{\mathrm{a}, \mathrm{b}}$, Mariana

6 Perez Rocha $^{\mathrm{a}, \mathrm{c}}$, Katri E. Tolonen ${ }^{\mathrm{a}, \mathrm{b}}$, Kimmo T. Tolonen ${ }^{\mathrm{a}}$, and Jani Heino ${ }^{\mathrm{a}}$

7

8 a Finnish Environment Institute, Natural Environment Centre, Biodiversity, Paavo Havaksen

9 tie 3, 90530 Oulu, Finland

$10 \quad{ }^{b}$ Ecology Research Unit, University of Oulu, Finland

$11{ }^{\mathrm{c}}$ Geography Research Unit, University of Oulu, Finland

12

13 Correspondence: Annika Vilmi, tel. +358 401677 504, e-mail: annika.vilmi@gmail.com 14

15 Word count: 6878 


\section{Abstract}

17 Different components of global change (e.g. climate change, land use, pollution and introduced species) continue to alter biodiversity worldwide. As northern regions are still relatively undisturbed and will likely face clear increases in temperature in the near-future, we examined the signs of biodiversity change due to anthropogenic stressors using a systematic review of previous studies. Our aim was to map where, in which way and due to which stressor biodiversity in northern regions has changed. We made a systematic literature search covering the years between 2000 and 2015 to obtain a comprehensive selection of recent research. As species richness was clearly the most commonly used indicator of biodiversity, we only concentrated on this aspect of biodiversity. We compared different biological groups, regions and ecosystems. In the majority of the cases, anthropogenic stressors had decreased species richness, or had no effects on it, while increasing or multiple effects of stressors on species richness were less common. Freshwater ecosystems were most sensitive to anthropogenic stressors, as species richness often decreased due to these stressors. The effects of land use on richness were covered relatively widely in the selected set of articles, but the effects of other components of global change on species richness require further attention. Despite the fact that pollution was not as commonly studied stressor as land use, it was the most harmful stressor type affecting species richness. Geographically, most studies were located in boreal Canada or Fennoscandia, while no studies were executed in vast circumpolar areas where the temperature rise has been greatest and the projected climate change is likely to be fast. Overall, we could find an alarmingly small set of studies that described the effects of actual anthropogenic stressors in real-life circumstances in northern high latitudes.

40 Keywords: anthropogenic stress, Arctic, biodiversity, boreal, climate change, high latitudes 
The increase of human population size and massive consumption of natural resources have led to the ongoing global environmental change. Components of human-induced global change include, for instance, increased greenhouse gas concentrations in the atmosphere, land use alteration, environmental pollution including nutrient loading, and introduction of nonnative species (Vitousek 1994; Chapin III et al. 2000). Some researchers have even proposed that human activities have led to a new geological epoch (Table 1), the Anthropocene (Lewis and Maslin 2015; Waters et al. 2016). During the Anthropocene, global changes have already affected biodiversity in several and often intertwined ways (Chapin III et al. 2000; Butchart et al. 2010; Vörösmarty et al. 2010; Maxwell et al. 2016). Moreover, numerous studies have indicated that collapses of biodiversity due to global change may jeopardize ecosystem functions and services essential to the life, societies and economies of humankind (Worm et al. 2006; Cardinale et al. 2012; Vanbergen et al. 2013). Not even the generally sparselypopulated northern high latitudes are safe from these human interventions and increased utilisation of land and water, which form major disturbances to northern ecosystems (ACIA 2005; Halpern et al. 2008). Emissions of greenhouse gases are currently highest in history. They have led to changes in climate which have affected both human and natural systems as warming of the atmosphere and oceans, reduction of snow and ice covers, and rising of the sea level. The northern parts of the world will likely face the highest degrees of warming (IPCC 2013),

61 simultaneously affecting biodiversity in these vulnerable high-latitude regions (Chapin III et al. 2000; Post et al. 2009). Climate change has already affected northern ecosystems and biological communities in terrestrial (e.g. Aalto et al. 2014), freshwater (e.g. Nilsson et al. 2015) and marine realms (e.g. Kortsch et al. 2015). It has been predicted that by the end of this century, climate change will be the most important driver of biodiversity change in the 
arctic and boreal areas (Sala et al. 2000). The warming trend will likely change many aspects of high-latitude biodiversity, such as distributions and abundances of species, the extent and distribution of habitats, and introduction and spread of non-native species (e.g. ACIA 2005). In addition to global warming, other human activities, such as timber harvesting, agriculture and industry, have transformed northern high-latitude areas and changed the land cover to a considerable degree (e.g. McGuire et al. 2007). Although there are still some relatively pristine, large boreal forest areas left (e.g. Boonstra et al. 2016), boreal forests are often shaped by silvicultural practices which modify the natural ecosystems of this vast biome. The management of boreal forests alters the spatial qualities of these habitats, thus possibly affecting occurrences of species that require continuous forest landscapes for dispersal (Reunanen et al. 2010). Furthermore, development of industrial and urban landscapes (e.g. ACIA 2005) and construction of roads (e.g. Trombulak and Frissell 2000) can also cause habitat fragmentation, posing a severe threat to biodiversity (e.g. Hanski 2015). In the marine realm, the utilisation of marine areas for oil and gas drilling and fish farming, for example, can change the ecosystem and biodiversity by altering habitat conditions (e.g. ACIA 2005). Species introductions to new areas by humans are closely linked to land use changes. Hot-spots of alien species may occur near major human settlement areas (e.g. Wasowicz et al. 2013) or along roads (e.g. Trombulak and Frissell 2000). Alien species are typically introduced to new regions unintentionally (e.g. Spaulding and Elwell 2007), but some species are deliberately moved to new regions (e.g. Josefsson and Andersson 2001). In aquatic ecosystems, major introduction pathways of alien species are the ballast waters of ships and aquaculture (Molnar et al. 2008; Chan et al. 2014). Shipping-related transportation may become a severe problem if ship traffic increases due to more pronounced melt of Arctic sea 
91

92

93

94

95

96

97

98

99

100

101

102

103

104

105

106

107

108

109

110

111

112

113

114

115

poor, and the introduction of new species to these regions can severely affect native

biodiversity and ecosystem functioning in both terrestrial and aquatic realms (e.g. ACIA

2005). Importantly, the warming temperatures may favour alien species invasions while disfavouring native species (e.g. Wasowicz et al. 2013).

Human activities also deteriorate air quality, which further affects biodiversity in high latitudes. Airborne pollution and direct input of pollutants to ecosystems can alter both terrestrial and aquatic biotas. Airborne carbon emissions threaten to acidify especially highlatitude marine ecosystems (e.g. Steinacher et al. 2009). Pollution from industry, such as mining and smelters, can also affect biodiversity at local scales (ACIA 2005; Zvereva and Kozlov 2011). Nutrient enrichment can pose a threat to biodiversity especially in freshwater (e.g. Vörösmarty et al. 2010) and marine ecosystems (e.g. ACIA 2005). Also, other types of alien products entering the ecosystems exist. In marine ecosystems, pollution in the form of plastic (e.g. Trevail et al. 2015), or fish feces and veterinary products from fish farms can be released to the water. Furthermore, associated with shipping and oil industry, oil discharges entering nature are relatively common (e.g. ACIA 2005).

Considering the variety of anthropogenic changes that Arctic and boreal areas have already faced or will likely face in the near future, we systematically reviewed studies conducted in these northern areas. Specifically, our aim was to map (1) where, (2) in which way, and (3) due to which stressor biodiversity in northern regions has changed. We searched for research papers that studied the effects of anthropogenic stressors on the diversity of biological communities. We excluded all types of manipulative (including micro- and mesocosm) studies in order to concentrate only on actual changes taking place at natural spatial scales. To find out the main trends between the on-going global alterations and biodiversity changes, we included all aquatic and terrestrial habitats, as well as all biological groups in our systematic review. We will provide a general picture of where and what kind of 
changes in biodiversity have already happened, or at least what has been studied by now. We

117 also address research gaps from spatial, organismal, ecosystem or stressor perspectives.

\section{Selection criteria and methods}

To find suitable articles, we selected appropriate keywords related to our themes of interest and conducted a search in the Web of Knowledge (http://apps.webofknowledge.com). We used three types of keywords: 1) words that describe the northern regions (arctic OR "high latitude*" OR "high-latitude*" OR subarctic OR boreal OR polar); 2) words that are related to global change (anthropogenic OR human* OR * pristine OR natural OR eutrophication OR "nutrient enrichment" OR "habitat fragmentation" OR "land use*" OR "invasive species" OR "alien species" OR acidification OR "climate change" OR "climate warming"), and 3) words that are related to biodiversity (*diversit* OR richness OR evenness). We used these search terms simultaneously and, for all rows, TOPIC was selected. We searched for articles published between 2000 and 2015. The main search for suitable articles was done on December 28, 2015 with a total of 3352 search results. To check if there were any more articles added into the database matching with our search terms, one more search was done on February 12, 2016 with a total of 3394 search results.

All authors were given an equal share of search results to go through and select articles suitable for our scope. To ensure that the selection of articles was consistently made and to guarantee high level of objectivity in the selection process, the first author double-checked all selected articles. We selected articles that reported findings from northern areas (i.e. Arctic

137 and boreal regions) and dealt with the effects of anthropogenic stressors on biological diversity of community-level data. In order to get selected, the article had to include a clear comparative research layout (anthropogenic stress vs. no anthropogenic stress, anthropogenic stress vs. natural stress, or an anthropogenic stress gradient). We attempted to include only 
studies focusing on real-life situations, and thus we did not include any experimental or manipulative studies. This is because we were interested to see whether there were any actual trends reported regarding northern biodiversity change. We also did not include studies that used a space-for-time substitution to illustrate the effects of e.g. climate change, studies that tested ecological theories only, studies that did not have any clear stressors, purely predictive studies, review papers or conference abstracts. These types of articles were numerous in the initial search results and thus several exclusions were made. In addition, there were some articles that did not clearly state their findings, and to refrain from making our own deductions, we did not include such articles in the final set of articles either.

All authors collected information from articles that were likely suitable for comparative purposes (see Table S1 in Supplementary material). Again, to ensure the uniform quality of the data, the first author double-checked all collected information and made final decisions on which articles to select. At this point, as it was clear that taxonomic richness was the most commonly-used aspect of biodiversity in the selected papers, we decided to concentrate on that aspect of biodiversity only. Richness was usually assessed at species level, so from now on we use the term species richness to describe the taxonomic richness of the studies included. The popularity of assessing species richness in the studies found is understandable as species richness is the most commonly-measured aspect of biodiversity (Gaston 2000). After the data were collected, we formed a number of categories from different variables. For example, we formed five stressor type categories (i.e. climate change, land use, 161 pollution, introduced species and miscellaneous stressors; see Table S2). We also formed nine major groups of biological organisms (i.e. plants, lichen, fungi, algae, bacteria, invertebrates, fish, birds, mammals; see Table S3). The main terms we use along with explanations are presented in Table 1. As we titled the five stressor type categories as presented in Table 1, we did one more additional search for articles in the Web of Knowledge 
(http://apps.webofknowledge.com) on July 20, 2016, to ensure that introduced species and pollution were properly acknowledged in the search. The search terms were identical to the original search apart from the second row, which had only two keywords on it ("introduced species" OR pollution). There were 167 search results, which the first author checked and selected articles if suitable for this review. Finally, the first author compiled a consistent final data table including main information and variables from the final set of 90 selected articles that fulfilled our criteria. As some of the selected articles studied species richness of multiple biological groups, the final amount of separate data points in this review was 104 . For the final data table, see Table S4, and for the list of selected articles, see Table S5.

Our specific focus was to illustrate findings as cartographic presentations. For this purpose, we used the continuous southern border of the boreal biome delineated using the World Wildlife Fund terrestrial ecoregions map (Potapov et al. 2008) as the southern limit of our research area. We also extrapolated this border to marine areas. To increase the amount of cartographic information, we presented mean annual air temperature isotherms (Hijmans et al. 2005) and NDVI (normalized difference vegetation index; Tucker 1979; Didan 2015) in the maps as well. The approximate locations of the studies in the publications selected are presented as a map in Fig. S6. The ID-number on the map and on the list of selected articles (Table S5) is the connecting feature.

\section{Geographic clusters and gaps of research in the North}

We found 90 publications with 104 data points that passed our sieve. Most studies described species richness-stressor relationships occurring in the southern provinces of Canada or throughout Fennoscandia (Fig. 1, Fig. 2). In the continent of North America, vast Arctic regions in Alaska and northern provinces territories of Canada have not been such thoroughly studied in the context of species richness-global change relationships. Furthermore, our 
systematic review showed that species richness-stressor relationships in Russia and the high Arctic in general have been relatively seldom studied or they have been presented in nonEnglish and/or non-peer-reviewed publications. Thus, in that sense, almost the entire circumpolar area presents a geographical research gap. As human activities, such as shipping, oil extraction and mining, increase (AMAP 2012; Clement et al. 2013; Rhéaume and CaronVuotari 2013), and as temperatures have been observed to rise in this area (IPCC 2013), research needs to be focused on these still relatively natural, but constantly changing Arctic areas. Importantly, the circumpolar research gap presents an area where climate warming is predicted to be strongest compared to other parts of the world (IPCC 2013). Our map illustrations (e.g. Fig. 1) show that there are few studies conducted in the region where the mean annual air temperature is below $-5^{\circ} \mathrm{C}$ (comparable to the zone of continuous permafrost and extensive carbon pools; Schuur et al. 2015), thus representing a need for biodiversity research focusing on especially cold environments. Likewise, most research has been focused on the areas with high productivity indicated by NDVI in our maps. What is also important to acknowledge when assessing species richness-stressor relationships in high-latitude regions is the fact that these northern ecosystems go through four seasons, and biological organisms are adapted to such change of seasons. Regarding climate change, especially winter temperatures will likely increase the most, while summer temperatures are predicted to increase only moderately (ACIA 2005; IPCC 2013). This seasonal difference in increasing temperatures

210 may further alter the complex relationships between components of global change and 211 biodiversity.

\section{Anthropogenic stress usually decreases or has no effects on species richness}

214 When considering the relationships between anthropogenic stressors and species richness of 215 different biological groups, negative effects of stressors on species richness were detectable 
216 in one third of the cases (Fig. 1). Furthermore, one third of the cases showed no relationship

217 between species richness and any stressor, while increasing and multiple effects were clearly

218 less common. Anthropogenic global change thus affects species richness in various ways at

219 northern high latitudes, and not all effects are entirely negative or positive. This is

220 understandable as the relationships between biodiversity and stressors may be very complex

221 (e.g. Garcia et al. 2014), biotic interactions modify them (e.g. Schmitz et al. 2003; Olofsson

222

et al. 2013), biological communities may resist certain degrees of stress, or different stressors

223

have antagonistic effects on each other (Annala et al. 2014; Jackson et al. 2016). It is

224

however important to notice that increasing stress intensities or occurrences, probable in the

near future (ACIA 2005; Garcia et al. 2014; Nilsson et al. 2015), may affect species richness

in other, non-predictable ways. In addition, usually there are multiple stressors

simultaneously affecting biodiversity (ACIA 2005; Heino et al. 2009).

Geographically, there were some areas where species richness showed uniform responses to human-induced stress (Fig. 1). For instance, in the Boreal Plains of western

230 Canada species richness usually had changed in some way due to anthropogenic stress. In

231 Fennoscandia, species richness seldom increased in response to human activities. Multiple responses were more common in Fennoscandia than in North America. There were also some areas (e.g. in south-eastern Canada) where species richness typically had not reacted to anthropogenic stressors at all. In general, however, species richness throughout the northern

235 region showed several types of responses to different components of global change. In

236 addition, there were no clear trends observable between species richness responses and mean annual air temperature or productivity. Further research conducted at the coldest latitudes or areas with lower productivity might confirm or alter this finding. 
240 Terrestrial ecosystems were most commonly studied, with altogether 60 publications (Fig.

241 3a). We also found 27 publications on freshwater ecosystems, but only three publications on

242 marine ecosystems. Regarding the publications concentrating on terrestrial ecosystems, 70\%

243 of the publications showed that species richness had changed due to human actions.

244 Terrestrial species richness had relatively evenly decreased, increased or exhibited multiple

245 responses due to anthropogenic stressors. Half of the studies conducted in freshwater

246 ecosystems, however, showed a negative relationship between species richness and an

247 anthropogenic stressor. Thus, it seems that freshwater biodiversity in northern regions is very

248 sensitive to different components of global change (see also Heino et al. 2009). Freshwater

249 species richness is, furthermore, more threatened in the future, as precipitation is predicted to 250 increase in the northern regions (IPCC 2013). The increasing rainfall may alter catchment properties, ecosystem structure and function (ACIA 2005; Garssen et al. 2015; Lind et al. 2015).

Regarding marine ecosystems, all three studies showed that species richness had changed due to human stress (Fig. 3a). Overall, we were surprised to find only few marine studies dealing with anthropogenic effects on species richness. It is possible that such studies do exist, but they were not captured with our search criteria or that those studies are simply rare in northern regions. Moreover, marine systems differ remarkably from terrestrial and 258 freshwater systems, and thus traditional response-stressor studies may be more difficult to 259 conduct. Overall, the circumpolar research gap is at least partly linked to the absence of marine studies. There is thus a need for studies focusing on marine species richness-stressor relationships in northern high latitudes. 
263 For the entire northern region, most studies concentrated on species richness of either

264 invertebrates or plants (Fig. 1, Fig. 3b). Birds were also a relatively commonly-studied

265 biological group, followed by fungi and lichens which were more commonly studied in

266 Fennoscandia than in other northern areas. Species richness of fish and mammals were

267 surprisingly studied only in one paper each. Fish and mammals may be more commonly

268 studied as single species (Carey and Zimmerman 2014; Sonsthagen et al. 2014) and in

269 general ecological studies (Korsu et al. 2012; Hein et al. 2014), whereas studies on the effects

270 of stressors on their species richness seem to be less common at northern high latitudes.

271 Species richness of bacteria (i.e. richness of operational taxonomic units) was studied in two

272 publications only. Algae, containing traditionally-studied biological groups such as phytoplankton, were neither also not studied very often in the context of anthropogenic

274 stressors and species richness. Perhaps nowadays algae are used for testing ecological theories (e.g. Heino et al. 2010), or more complex indices than species richness are applied 276 (e.g. Lavoie et al. 2009).

277

\section{Different responses of species richness within and between biotic groups}

All biological groups that were studied more than once showed varying responses to anthropogenic stressors (Fig. 1, Fig. 3b). In other words, the relationship between a stressor and a biological group is not straightforward, but can be rather complex and probably context-dependent (Sala et al. 2000; Woodward et al. 2010; Garcia et al. 2014). Again, among many things, biotic interactions (e.g. Woodward, 2009), spatial scale (e.g. Garcia et al. 2014) and regional characteristics (e.g. Bell et al. 2014) may affect the observed relationships. For instance, in some study settings, although concentrating on one stressor only while in fact multiple stressors were present, the effects of the stressor studied may be 
attenuated (e.g. Ormerod et al. 2010). It is also possible that biological communities show multiple responses to stress (Bell et al. 2014; Johnson and Angeler 2014).

The two most commonly-studied biological groups, plants and invertebrates, showed somewhat different trends regarding species richness responses to anthropogenic stress. Species richness of plants increased twice as often as species richness of invertebrates, which in turn decreased twice as often compared to that of plants (Fig. 1, Fig. 3b). Additionally, fungi and lichens, both present in terrestrial ecosystems, showed contrasting responses to components of global change. Species richness of fungi more often showed decreasing responses to anthropogenic stressors, whereas species richness of lichens usually did not react to the stressors.

\section{Land use the most studied stressor, but pollution most harmful to species richness}

Land use, especially forestry, was the most studied stressor type over the entire northern region (Fig. 2, Fig. 3c, S4). This is understandable because silviculture is a major human activity across the vast boreal forest biome (e.g. Moen et al. 2014). Pollution was the second most commonly-studied stressor type, followed by climate change and miscellaneous stressor types. Climate change can be a particularly challenging stressor to study, because reliable measurement of the effects typically requires a time-series of samples that is linked to temperatures (see also Post et al. 2009). Miscellaneous stressor types included multiple stressor types in our grouping. Importantly, as the situation with multiple stressors is probably the most common in nature (ACIA 2005; Ormerod et al. 2010), there is a strong need for studies that observe the effects of many simultaneously-acting stressors on species richness (see also Post et al. 2009). From the major components of global change, introduced species were the least studied stressor type in northern regions. More information is thus needed on the effects of introduced species, as species introductions are predicted to increase 
312 due to global change (e.g. Ware et al. 2014). Even though introduced species have surely

313 been studied, those studies typically concentrate on describing the distributional changes of

314 invasive species or pair-wise interactions between the introduced and some native species

315 (Leppäkoski and Olenin 2000; Hein et al. 2014).

316 Human-induced stressors can cause both positive and negative changes in biodiversity

317 (Garcia et al. 2014; Lind et al. 2014), which was also shown for northern areas in our

318 systematic review. For instance, land use showed approximately similar amounts of

319 increasing, multiple and decreasing effects on species richness, while the proportion of "no

320 effects" was pronounced when compared to the other stressor types. Climate change, in

321 general, showed multiple effects on species richness. Miscellaneous stressor types and

322 especially pollution usually decreased species richness (see also Zvereva and Kozlov 2011).

323 Consequently, the stressor types had different effects on species richness.

324

\section{Conclusions}

326 In northern regions, global change research on real-life species richness-stressor relationships

327 was surprisingly sparsely conducted both in quantity and in the spatial context. There were vast areas where no research has been made, which is alarming as northern high latitudes will likely face strongest changes due to global change (ACIA 2005; IPCC 2013). It is of course possible that there were publications we could not find using the specific keywords, but we are confident that the publications we included in this systematic review represent a good selection of recent research conducted in northern ecosystems. Hence, we conclude that there is a geographical research gap throughout the northern circumpolar area that deserves further attention regarding the biodiversity-stressor relationships. Importantly, considering the projected rate of future changes, the need for more research is urgent. 
337 changed due to an anthropogenic stressor than had remained unaffected by stressors. More

338 specifically, a decreasing trend of species richness was the most common type of response,

339 although there were also many types of other responses. Different biological groups showed

340 relatively similar distributions of responses in their species richness with a few exceptions. Of

341 the three different ecosystem types, species richness in freshwater ecosystems most often

342 showed a decrease in response to an anthropogenic stressor. This is an important finding for

343 policymakers to acknowledge. It is highly important to reduce the effects of stressors in these

344 ecosystems because the net effects are usually negative (e.g. Jackson et al. 2016).

345 Of the components of global change, land use change was clearly the most widely-

346 studied stressor type. Although not as commonly studied, pollution was most often related to

347 a decrease in species richness, thus posing a clear threat to species richness in northern high

348 latitudes. More research is needed on the species richness-stressor relationships regarding the

349 effects of climate change, introduced species and pollution. Surprisingly, studies addressing

350 the effects of multiple stressor types to biodiversity were exceptionally few. This trend

351 represents a need for more research focusing on multiple stressors acting in concert, which, in

352 the end, is the most common situation in nature (see also Halpern et al. 2008; Jackson et al.

353 2016; Titeux et al. 2016). 


\section{Acknowledgements}

355 The authors thank Dr. Satu Maaria Karjalainen for constructive discussions. The authors also 356 acknowledge the Academy of Finland, Emil Aaltonen Foundation, Ministry of Education of

357 Brazil and "Science Without Borders", and Maj and Tor Nessling Foundation for financial 358 support. The authors have no conflicts of interests to declare. 


\section{References}

Aalto, J., Venäläinen, A., Heikkinen, R.K., and Luoto, M. 2014. Potential for extreme loss in high-latitude Earth surface processes due to climate change. Geophys. Res. Lett. 41: $3914-3924$.

ACIA. 2005. Arctic Climate Impact Assessment. Cambridge University Press, pp. 1042.

AMAP. 2012. Arctic Climate Issues 2011: Changes in Arctic Snow, Water, Ice and Permafrost. Arctic Monitoring and Assessment Programme (AMAP), Oslo. SWIPA 2011 Overview Report, pp. 97.

Annala, M., Mykrä, H., Tolkkinen, M., Kauppila, T., and Muotka, T. 2014. Are biological communities in naturally unproductive streams resistant to additional anthropogenic stressors? Ecol. Appl. 24: 1887-1897.

Bell, F.W., Hunt, S., Dacosta, J., Sharma, M., Larocque, G.R., Winters, J.A., and Newmaster, S.G. 2014. Effects of Silviculture Intensity on Plant Diversity Response Patterns in Young Managed Northern Temperate and Boreal Forests. Ecoscience 21: 327-339.

Boonstra, R., Andreassen, H.P., Boutin, S., Hušek, J., Ims, R.A., Krebs, C.J., Skarpe, C., and Wabakken, P. 2016. Why Do the Boreal Forest Ecosystems of Northwestern Europe Differ from Those of Western North America? BioScience. doi: 10.1093/biosci/biw080.

Butchart, S.H.M., Walpole, M., Collen, B., van Strien, A., Scharlemann, J.P., Almond, R.E., Baillie, J.E., Bomhard, B., Brown, C., Bruno, J., Carpenter, K.E., Carr, G.M., Chanson, J., Chenery, A.M., Csirke, J., Davidson, N.C., Dentener, F., Foster, M., Galli, A., Galloway, J.N., Genovesi, P., Gregory, R.D., Hockings, M., Kapos, V., Lamarque, J.F., Leverington, F., Loh, J., McGeoch, M.A., McRae, L., Minasyan, A., Hernández Morcillo, M., Oldfield, T.E., Pauly, D., Quader, S., Revenga, C., Sauer, J.R., Skolnik, B., Spear, D., Stanwell-Smith, D., Stuart, S.N., Symes, A., Tierney, M., Tyrrell, T.D., 
Vié, J.C., and Watson, R. 2010. Global biodiversity: indicators of recent declines. Science 328: 1164-1168.

386

387

Cardinale, B.J., Duffy, E., Gonzalez, A., Hooper, D.U., Perrings, C., Venail, P., Narwani, A., Mace, G.M., Tilman, D., Wardle, D.A., Kinzig, A.P., Daily, G.C., Loreau, M., Grace, J.B., Larigauderie, A., Srivastava, D., and Naeem, S. 2012 Biodiversity loss and its impacts on humanity. Nature 486: 59-67.

Carey, M.P., and Zimmerman, C.E. 2014. Physiological and ecological effects of increasing temperature on fish production in lakes of Arctic Alaska. Ecol. Evol. 4: 1981-1993.

Chapin III, F.S., Zavaleta, E.S., Eviner, V.T., Naylor, R.L., Vitousek, P.M., Reynolds, H.L., Hooper, D.U., Lavorel, S., Sala, O.E., Hobbie, S.E., Mack, M.C., and Díaz, S. 2000. Consequences of changing biodiversity. Nature 405: 234-242.

Chan, F.T., Briski, E., Bailey, S.A., and MacIsaac, H.J. 2014. Richness-abundance relationships for zooplankton in ballast water: temperate versus Arctic comparisons. ICES Journal of Marine Science. doi: 10.1093/icesjms/fsu020.

Clement, J.P., Bengtson, J.L., and Kelly, B.P. 2013. Managing for the future in a rapidly changing Arctic. Interagency Working Group on Coordination of Domestic Energy Development and Permitting in Alaska.

Didan, K. 2015. MOD13C1 MODIS/Terra Vegetation Indices 16-Day L3 Global 0.05Deg CMG V006. NASA EOSDIS Land Processes DAAC. doi: 10.5067/MODIS/MOD13C1.006.

Eicken, H. 2013. Arctic sea ice needs better forecasts. Nature 497: 431-433.

Garcia, R.A., Cabeza, M., Rahbek, C., and Araujo, M.B. 2014. Multiple dimensions of climate change and their implications for biodiversity. Science 344: 1247579. 
Garssen, A.G., Baattrup-Pedersen, A., Voesenek, L.A., Verhoeven, J.T., and Soons, M.B. 2015. Riparian plant community responses to increased flooding: a meta-analysis. Glob. Chang. Biol. 21: 2881-2890.

Gaston, K.J. 2000. Global patterns in biodiversity. Nature 405: 220-227.

Halpern, B.S., Walbridge, S., Selkoe, K.A., Kappel, C.V., Micheli, F., D'Agrosa, C., Bruno, J.F., Casey, K.S., Ebert, C., Fox, H.E., Fujita, R., Heinemann, D., Lenihan, H.S., Madin, E.M., Perry, M.T., Selig, E.R., Spalding, M., Steneck, R., and Watson, R. 2008. A global map of human impact of marine ecosystems. Science 319: 948-952.

Hanski, I. 2015. Habitat fragmentation and species richness. J. Biogeogr. 42: 989-994.

Hein, C.L., Öhlund, G., and Englund, G. 2014. Fish introductions reveal the temperature dependence of species interactions. Proc. R. Soc. B 281: 20132641. doi: $10.1098 / \mathrm{rspb} .2013 .2641$

Heino, J., Bini, L.M., Karjalainen, S.M., Mykrä, H., Soininen, J., Vieira, L.C.G., and DinizFilho, J.A.F. 2010. Geographical patterns of micro-organismal community structure: are diatoms ubiquitously distributed across boreal streams? Oikos 119: 129-137.

Heino, J., Virkkala, R., and Toivonen, H. 2009. Climate change and freshwater biodiversity: detected patterns, future trends and adaptations in northern regions. Biol. Rev. 84: 39_ 54.

Hijmans, R.J., Cameron, S.E., Parra, J.L., Jones, P.G., and Jarvis, A. 2005. Very high resolution interpolated climate surfaces for global land areas. Int. J. Climatol. 25: 19651978.

IPCC. 2013. Climate Change 2013. World Meteorological Organization. Fifth Assessment Report. 
Jackson, M.C., Loewen, C.J.G., Vinebrooke, R.D., and Chimimba, C.T. 2016. Net effects of multiple stressors in freshwater ecosystems: a meta-analysis. Glob. Chang. Biol. 22: $180-189$.

Johnson, R.K., and Angeler, D.G. 2014. Effects of agricultural land use on stream assemblages: Taxon-specific responses of alpha and beta diversity. Ecol. Indic. $\mathbf{4 5}$ : 386-393.

Joseffson, M., and Andersson, B. 2001. The Environmental Consequences of Alien Species in the Swedish Lakes Mälaren, Hjälmaren, Vänern and Vättern. AMBIO 30: 514-521.

Korsu, K., Heino, J., Huusko, A., and Muotka, T. 2012. Specific niche characteristics facilitate the invasion of an alien fish invader in boreal streams. International Journal of Ecology. doi:10.1155/2012/813016.

Kortsch, S., Primicerio, R., Fossheim, M., Dolgov, A.V., and Aschan, M. 2015. Climate change alters the structure of arctic marine food webs due to poleward shifts of boreal generalists. Proc. R. Soc. B 282: 20151546.

Lavoie, I., Hamilton, P.B., Wang, Y-K., Dillon, P.J., and Campeau, S. 2009. A comparison of stream bioassessment in Québec Canada using six European and North American diatom-based indices. Nova Hedwigia 135: 37-56.

Leppäkoski, E., and Olenin, S. 2000. Non-native Species and Rates of Spread: Lessons from the Brackish Baltic Sea. Biol. Invasions 2: 151-163.

Lewis, S.L., and Maslin, M.A. 2015. Defining the Anthropocene. Nature 519: 171-180.

Lind, L., Nilsson, C., Polvi, L.E., and Weber, C. 2014. The role of ice dynamics in shaping vegetation in flowing waters. Biol. Rev. 89: 791-804.

Maxwell, S.L., Fuller, R.A., Brooks, T.M., and Watson, J.E.M. 2016. Biodiversity: The ravages of guns, nets and bulldozers. Nature 536: 143-145. 
McGuire, A.D., Chapin III, F.S., Wirth, C., Apps, M.J., Bhatti, J.S., Callaghan, T., Christensen, T.R., Clein, J.S., Fukuda, M., Maximov, T., Omuchin, A., Shvidenko, A., and Vaganov, E. 2007. Responses of high latitude ecosystems to global change: potential consequences for the climate system. In Terrestrial Ecosystems in a Changing World. Edited by Canadell, J.G., Pataki, D.E., and Pitelka, L.F. The IGBP Series, Springer, pp. 297-310.

Moen, J., Rist, L., Bishop, K., Chapin, F.S., Ellison, D., Kuuluvainen, T., Petersson, H., Puettmann, K.J., Rayner, J., Warkentin, I.G., and Bradshaw, C.J.A. 2014. Eye on the Taiga: Removing global policy impediments to safeguard the boreal forest. Conserv. Lett. 7: 408-418.

Molnar, J.L., Gamboa, R.L., Revenga, C., and Spalding, M.D. 2008. Assessing the global threat of invasive species to marine biodiversity. Front. Ecol. Environ. 6: 485-492.

Nilsson, C., Polvi, L.E., and Lind, L. 2015. Extreme events in streams and rivers in arctic and subarctic regions in an uncertain future. Freshwater Biol. 60: 2535-2546.

Olofsson, J., te Beest, M., and Ericson, L. 2013. Complex biotic interactions drive long-term vegetation dynamics in a subarctic ecosystem. Philos. Trans. R. Soc. B. doi: 10.1098/rstb.2012.0486.

Ormerod, S.J., Dobson, M., Hildrew, A.G., and Townsend, C.R. 2010. Multiple stressors in freshwater ecosystems. Freshwater Biol. 55: 1-4.

Post, E., Forchhammer, M.C., Bret-Harte, M.S. Callaghan, T.V., Christensen, T.R., Elberling, B., Fox, A.D., Gilg, O., Hik, D.S., Høye, T.T., Ims, R.A., Jeppesen, E., Klein, D.R., Madsen, J., McGuire, A.D., Rysgaard, S., Schindler, D.E., Stirling, I., Tamstorf, M.P., Tyler, N.J., van der Wal, R., Welker, J., Wookey, P.A., Schmidt, N.M., and Aastrup, P. 2009. Ecological dynamics across the Arctic associated with recent climate change. Science 325: 1355-1358. 
Potapov, P., Hansen, M.C., Stehman, S.V., Loveland, T.R., and Pittman, K. 2008. Combining MODIS and Landsat imagery to estimate and map boreal forest cover loss. Remote Sens. Environ. 112: 3708-3719.

Reunanen, P., Fall, A., and Nikula, A. 2010. Biodiversity and ecological forest-cover domains in boreal landscapes. Biodivers. Conserv. 19: 665-678.

Rhéaume, G., and Caron-Vuotari, M. 2013. The future of mining in Canada's north. The Conference Board of Canada.

Sala, O.E, Chapin III, F.S., Armesto, J.J., Berlow, E., Bloomfield, J., Dirzo, R., HuberSanwald, E., Huenneke, L.F., Jackson, R.B., Kinzig, A., Leemans, R., Lodge, D.M., Mooney, H.A., Oesterheld, M., Poff, N.L., Sykes, M.T., Walker, B.H., Walker, M., and Wall, D.H. 2000. Global biodiversity scenarios for the year 2100. Science 287: 17701774.

Schmitz, O.J., Post, E., Burns, C.E., and Johnston, K.M. 2003. Ecosystem responses to global climate change: Moving beyond color mapping. BioScience 53: 1199-1205.

Schuur, E.A.G., McGuire, A.D., Schädel, C. Grosse, G., Harden, J.W., Hayes, D.J., Hugelius, G., Koven, C.D., Kuhry, P., Lawrence, D.M., Natali, S.M., Olefeldt, D., Romanovsky, V.E., Schaefer, K., Turetsky, M.R., Treat, C.C., and Vonk, J.E. 2015. Climate change and the permafrost carbon feedback. Nature 520: 171-179.

Sonsthagen, S.A., Fales, K., Jay, C.V., Sage, G.K., and Talbot, S.L. 2014. Spatial variation and low diversity in the major histocompatibility complex in walrus (Odobenus rosmarus). Polar Biol. 37: 497-506.

Spaulding, S., and Elwell, L. 2007. Increase in nuisance blooms and geographic expansion of the freshwater diatom Didymosphenia geminata: Recommendations for response. US Environmental Protection Agency. 
Steinacher, M., Joos, F., Frölicher, T.L., Plattner, G-K., and Doney, S.C 2009. Imminent ocean acidification in the Arctic projected with the NCAR global coupled carbon cycleclimate model. Biogeosciences 6: 515-533.

Stroeve, J.C., Serreze, M.C., Holland, M.M., Kay, J.E., Malanik, J., and Barrett, A.P. 2012. The Arctic's rapidly shrinking sea ice cover: a research synthesis. Clim. Chang. 110: $1005-1027$.

Titeux, N., Henle, K., Mihoub, J-P., and Brotons, L. 2016. Climate change distracts us from other threats to biodiversity. Front. Ecol. Environ. 14: 291.

Trevail, A.C., Gabrielsen, G.W., Kühn, S., and Van Franeker, J.A. 2015. Elevated levels of ingested plastic in a high Arctic seabird, the northern fulmar (Fulmarus glacialis). Polar Biol. 38: 975-981.

Trombulak, S.C., and Frissell, C.A. 2000. Review of ecological effects of roads on terrestrial and aquatic communities. Conserv. Biol. 14: 18-30.

Tucker, C.J. 1979. Red and photographic infrared linear combinations for monitoring vegetation. Remote Sens. Environ. 8: 127-150.

Vanbergen, A.J., and the Insect Pollinators Initiative. 2013. Threats to an ecosystem service: pressures on pollinators. Front. Ecol. Environ. 11: 251-259.

Vitousek, P.M. 1994. Beyond global warming: ecology and global change. Ecology 75: $1861-1876$.

Vörösmarty, C.J., McIntyre, P.B., Gessner, M.O., Dudgeon, D., Prusevich, A., Green, P., Glidden, S., Bunn, S.E., Sullivan, C.A., Liermann, C.R., and Davies, P.M. 2010. Global threats to human water security and river biodiversity. Nature 467: 555-561.

Ware, C., Berge, J., Sundet, J.H., Kirkpatrick, J.B., Coutts, A.D.M., Jelmert, A., Olsen, S.M., Floerl, O., Wisz, M.S., and Alsos, I.G. 2014. Climate change, non-indigenous species 
and shipping: assessing the risk of species introduction to a high-Arctic archipelago. Divers. Distrib. 20: 10-19.

529

530

531

532

533

534

535

536

537

538

539

540

541

542

543

544

545

546

547

548

Wasowicz, P., Przedpelska-Wasovicz, E.M., and Kristinsson, H. 2013. Alien vascular plants in Iceland: Diversity, spatial patterns, temporal trends, and the impact of climate change. FLORA 208: 648-673.

Waters, C.N., Zalasiewicz, J., Summerhayes, C., Barnosky, A.D., Poirier, C., Galuszka, A., Cearreta, A., Edgeworth, M., Ellis, E.C., Ellis, M., Jeandel, C., Leinfelder, R., McNeill, J.R., Richter, D.deB., Steffen, W., Syvitski, J., Vidas, D., Wagreich, M., Williams, M., Zhisheng, A., Grinewald, J., Odada, E., Oreskes, N., and Wolfe, A.P. 2016. The Anthropocene is functionally and stratigraphically distinct from the Holocene. Science 351: $10.1126 /$ science. $\operatorname{aad} 2622$.

Woodward, G. 2009. Biodiversity, ecosystem functioning and food webs in fresh waters: assembling the jigsaw puzzle. Freshwater Biol. 54: 2171-2187.

Woodward, G., Perkins, D.M., and Brown, L.E. 2010. Climate change and freshwater ecosystems: impacts across multiple levels of organization. Philos. Trans. R. Soc. B 365: 2093-2106.

Worm, B., Barbier, E.B., Beaumont, N., Duffy, J.E., Folke, C., Halpern, B.S., Jackson, J.B., Lotze, H.K., Micheli, F., Palumbi, S.R., Sala, E., Selkoe, K.A., Stachowicz, J.J., and Watson, R. 2006. Impacts of biodiversity loss on ocean ecosystem services. Science 314: $787-790$.

Zvereva, E.L., and Kozlov, M.V. 2011. Impacts of Industrial Polluters on Bryophytes: a Meta-analysis of Observational Studies. Water Air Soil Poll. 218: 573-586. 
549 Table 1. A glossary of the main concepts used in this systematic review.

\begin{tabular}{|c|c|}
\hline Concept & Description \\
\hline Northern region & $\begin{array}{l}\text { Areas north from the southern border of the } \\
\text { continuous boreal biome (delineated according } \\
\text { to Potapov et al. 2008). }\end{array}$ \\
\hline Species richness & $\begin{array}{l}\text { We refer to all measures of taxonomic } \\
\text { richness as species richness, because species } \\
\text { level was the most studied taxonomic level in } \\
\text { the publications. }\end{array}$ \\
\hline Anthropocene & $\begin{array}{l}\text { Our current epoch, which witnesses the } \\
\text { overarching impacts of anthropogenic } \\
\text { stressors on our planet's geology and } \\
\text { ecosystems (Waters et al. 2016). }\end{array}$ \\
\hline Global change & $\begin{array}{l}\text { All anthropogenic actions that have led to a } \\
\text { global change of the Earth. }\end{array}$ \\
\hline Climate change & Human-induced climate warming. \\
\hline Land use change & $\begin{array}{l}\text { All kinds of anthropogenic landscape } \\
\text { alterations (e.g. forestry, road building). }\end{array}$ \\
\hline Pollution & $\begin{array}{l}\text { Any non-natural matter that enters natural } \\
\text { ecosystems due to human actions (e.g. } \\
\text { nutrients, noise, road salt). }\end{array}$ \\
\hline Introduced species & $\begin{array}{l}\text { Alian species introduced to a new area due to } \\
\text { human actions. }\end{array}$ \\
\hline $\begin{array}{l}\text { Miscellaneous } \\
\text { stressors }\end{array}$ & $\begin{array}{l}\text { Miscellaneous stressors (e.g. water regulation, } \\
\text { recreation, wildlife management) or multiple } \\
\text { stressor types. }\end{array}$ \\
\hline
\end{tabular}




\section{Figure captions}

551 Fig. 1. A map illustrating where and in which way species richness of different biological

552 groups has responded to components of global change. The thick grey line indicates the

553 northern region with the southern limit determined by the extent of the continuous boreal

554 zone (Potapov et al. 2008), which is also extrapolated to marine areas. Mean annual air

555 temperature isotherms are presented as solid lines in the map (red line: $+5^{\circ} \mathrm{C}$, purple line $0^{\circ} \mathrm{C}$,

556 blue line $-5^{\circ} \mathrm{C}$; Hijmans et al. 2005). The background color of the map indicates productivity:

557 light green indicates high values of the normalized difference vegetation index (NDVI) and

558 light orange indicates low NDVI (there is no information on NDVI available from white

559 areas; Didan 2015).

560 Fig. 2. A map illustrating where and in which way different components of global change

561 have affected species richness. The thick grey line indicates the northern region with the

562 southern limit determined by the extent of the continuous boreal zone (Potapov et al. 2008),

563 which is also extrapolated to marine areas. Mean annual air temperature isotherms are

564 presented as solid lines in the map (red line: $+5^{\circ} \mathrm{C}$, purple line $0^{\circ} \mathrm{C}$, blue line $-5^{\circ} \mathrm{C}$; Hijmans

565 et al. 2005). The background color of the map indicates productivity: light green indicates

566 high values of the normalized difference vegetation index (NDVI) and light orange indicates

567 low NDVI (there is no information on NDVI available from white areas; Didan 2015).

568 Fig. 3. A general picture of how much and which ecosystems (a), biological groups (b) and

569 stressor types (c) have been studied in the context of the species richness-anthropogenic

570 stress relationship, and how species richness has changed due to anthropogenic stressors. 


\section{Supplementary material}

572 S1. Preliminary variables collected from articles.

573 S2. Main stressor categories and what they include.

574 S3. Biological groups and what they include.

575 S4. Final information collected from the selected articles.

576 S5. The list of selected articles.

577 S6. A map presenting the approximate locations of the studies reviewed. 